\title{
コロイド混合法により調製したムライト前駆体微粒子の 液中へテロ凝集構造の解析
}

\author{
趙 庸翼・神谷秀博・鈴木能大・堀尾正勒・鈴木久男* \\ 東京農工大学大学院生物システム応用化学研究科，184-8588 小金井市中町 2-24-16 \\ *静岡大学工学部物質工学科, 432 浜松市城北 3-5-1
}

\section{Mobility and Size-Distribution Analyses of Hetero-Coagulated Structures of Colloidally Mixed Mullite Precursor Suspensions and Their Sinterability}

\author{
Yong-Ick CHO, Hidehiro KAMIYA, Yoshio SUZUKI, Masayuki HORIO and Hisao SUZUKI* \\ Graduate School of Bio-Applications and System Engineering, Tokyo University of Agriculture and Technology, \\ 2-24-16, Nakamachi, Koganei-shi, Tokyo 184-8588 \\ *Department of Materials Science, Shizuoka University, 3-5-1, Johoku, Hamamatsu-shi, Shizuoka 432
}

\begin{abstract}
To control the hetero-coagulation structure of ultra-fine $\gamma-\mathrm{Al}_{2} \mathrm{O}_{3}$ and $\mathrm{SiO}_{2}$ powders for mullite ceramics, hetero-coagulation structures under different $\mathrm{pH}$ conditions were investigated by focusing on electrophoretic mobility and aggregate size distribution in suspensions. A bimodal electrophoretic mobility distribution was observed when precursor powders were prepared by colloidal mixing processes at $\mathbf{p H}=9.5$. Since each peak almost corresponded to the electrophoretic mobility of $\gamma-\mathrm{Al}_{2} \mathrm{O}_{3}$ and $\mathrm{SiO}_{2}$ particles, heterocoagulates were not formed in the suspension. In the case of $\mathrm{pH}=6.0$, weak hetero-coagulates were generated in suspension. However, uniform mixing could not be attained and large coagulates were formed. On the other hand, narrow and single mode electrophoretic mobility distribution was observed after colloidal mixing at $\mathrm{pH}=4.4$. It is concluded that the uniform hetero-coagulates for mullite precursor with the stoichiometric composition can be obtained. The change in structures of hetero-coagulates with $\mathrm{pH}$ conditions was analyzed by DLVO theory. Uniform and fine grained mullite ceramics were prepared from uniformly hetero-coagulated precursor powders mixed at $\mathrm{pH}=4.4$.
\end{abstract}

[Received July 30, 1997; Accepted October 3, 1997]

Key-words : Hetero-coagulation, $\xi$-potential, Electrophoretic mobility, Mullite precursor

\section{1. 緒 言}

ムライトは耐熱性, 耐高温クリープ特性に優れた材料である が，優れた耐高温クリープ特性を示す $\mathrm{Al}_{2} \mathrm{O}_{3} / \mathrm{SiO}_{2}$ 化学量論比 が極めて狭い範囲にある ${ }^{1) ~ 3) 。 ~}$ うに混合が不均一であった場合異相が生成しやすく，耐クリー

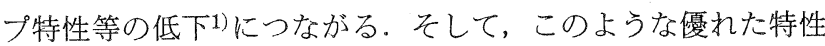
の化学量論組成高純度么ライトは難焼結性材料であり, 液相生 成温度以上の $1650^{\circ} \mathrm{C}$ 程度まで昇温しないと緻密化が困難であ る，高温での液相焼結では，異常粒成長により焼結体密度や強 度が低下する等の問題がある。高純度ムライトの易焼結化に は，分子設計的手法で化学量論組成に調製した前駆体超微粒子 を用いる方法4) 9) や $\gamma-\mathrm{Al}_{2} \mathrm{O}_{3}, \mathrm{SiO}_{2}$ 超微粒子をへテロ凝集させ るコロイドプロセス10) 15)などが検討されている。この中でコ ロイドプロセス法は合成条件の複雑な制御が不用であり，ムラ イト相生成温度以下の比較的低温でのアモルファスシリカの粘 性流動焼結による緻密化の可能性があるなどの特徵がある。し かし, 焼結時の緻密化挙動, 焼結体組織などに影響すると予測 されるコロイド粒子の凝集状態16)やへテロ凝集状態17)の均一 性等を定量的に評価し, 焼結微構造との関係を検討した研究は 少ない18)

本研究では， $\gamma-\mathrm{Al}_{2} \mathrm{O}_{3}$ と $\mathrm{SiO}_{2}$ 超敷粒子のコロイド混合時の $\mathrm{pH}$ によるへテロ凝集状態の変化をレーザードップラー法によ る電気泳動速度分布, 及び遠心沈降法による凝集粒子径分布に より評価し，へテロ凝集状態が焼結体微構造に及ぼす影響につ いて考察した.

\section{2. 実 験}

原料微粒子は $\gamma-\mathrm{Al}_{2} \mathrm{O}_{3}$ 微粒子（大明化学工業製， TM-100,
比表面積 $S_{\mathrm{w}}=134 \mathrm{~m}^{2} / \mathrm{g}$ ), 及び TEOS（テトラエトキシシラ ン)から合成した平均粒子径 $30 \mathrm{~nm} の \mathrm{SiO}_{2}$ 微粒子を用いた ${ }^{19)}$.

ムライト化学量論組成になるように $10.0 \mathrm{~g}$ の $\gamma-\mathrm{Al}_{2} \mathrm{O}_{3}$ を $3.9 \mathrm{~g}$ の $\mathrm{SiO}_{2}$ を含有するサスペンションに加え, 固体濃度12.6 vol\%のスラリーを作製した，混合時の $\mathrm{pH}$ は，図1に示した $\gamma-\mathrm{Al}_{2} \mathrm{O}_{3}$ 及び $\mathrm{SiO}_{2}$ 粒子の $\mathrm{pH}$ による゙ータ電位の変化から決 定した。 $\gamma-\mathrm{Al}_{2} \mathrm{O}_{3}$ の等電点は $\mathrm{pH}=9 \sim 9.5$ 付近に, $\mathrm{SiO}_{2}$ の等電 点は $\mathrm{pH}=3$ 付近にあり, ヘテロ凝集は $3<\mathrm{pH}<9.5$ の範囲で起 きると考えられる，そこで強いへテロ凝集が起きにくい $\gamma$ $\mathrm{Al}_{2} \mathrm{O}_{3}$ 粒子がほぼ等電点である $\mathrm{pH}=9.5$, 及びそれぞれの粒子 が明確に正負逆の電荷となる $\mathrm{pH}=4.4,6.0$ となるようアンモ二 ア水又は硝酸でスラリー $\mathrm{pH}$ を調整し, 直径 $3 \mathrm{~mm}$ のアルミナ ボールを用い $24 \mathrm{~h}$ ボールミル混合を行った. スラリー中のへテ

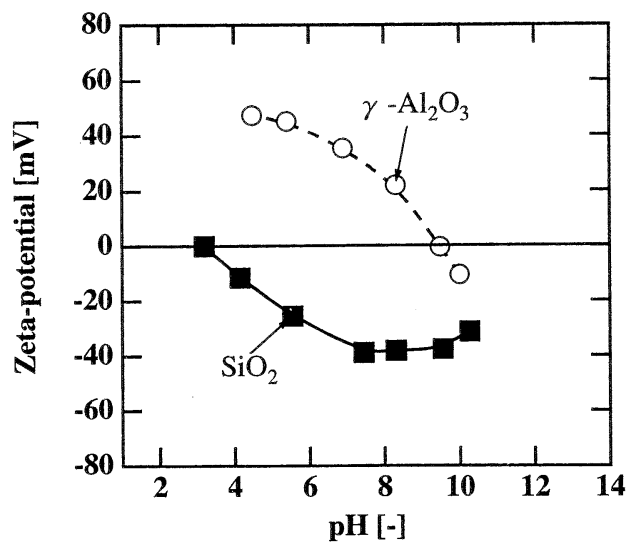

Fig. 1. Zeta-potentials of ultra-fine $\gamma-\mathrm{Al}_{2} \mathrm{O}_{3}$ and $\mathrm{SiO}_{2}$ particles. 
ロ凝集状態はレーザードップラー式電気泳動速度分布測定装置 （大塚電子製，LZ-800）により，凝集粒子径は遠心沈降式粒子 径分布測定装置（島津製作所製, SA-CP3）により評価した. ヘテロ凝集が起こる過程は $\mathrm{pH}=9.5$ で混合したスラリーを用 い $\mathrm{pH}$ を徐々に減少させて検討した。 また，ヘテロ凝集体の安 定性は $\mathrm{pH}=4.4$ の条件で調製したスラリーにアンモニア水を 加え $\mathrm{pH}$ を9.5まで増加させて検討した. $\mathrm{pH}=4.4,6.0,9.5$ の条 件でボールミル混合したスラリーを噴霧乾燥（ヤマト科学製, GB-22）し, 内径 $20 \mathrm{~mm}$ の金型で50 MPa で一軸成形した後, $1.0 \mathrm{GPa}$ の等方高压成形（三菱重工業製, MCT-100）を行っ た.この成形体を $20^{\circ} \mathrm{C} / \mathrm{min}$ の速度で昇温し, $1600^{\circ} \mathrm{C}$ で $2 \mathrm{~h}$ 保 持し焼結させた，得られた焼結体微構造を鏡面研磨後, 熱エッ チングして走査型電子顕微鏡 (SEM ; 日本電子製, JSMT100）による観察を行った。

\section{3. 結果及び考察}

\section{1 電気泳動法によるへテロ疑集状態の評価}

$\mathrm{pH}=4.4,6.0,9.5$ に調整した各スラリーを $24 \mathrm{~h}$ ボールミルで 混合した後, 電気泳動速度分布を測定した結果を図 2 に示し た.この図の横軸は静止帯上の粒子の電気泳動速度, 縦軸は各 泳動速度をもつ粒子の頻度分布である。図中の矢印は図 1 で
測定したゼータ電位の值から算出した各 $\mathrm{pH}$ での $\gamma-\mathrm{Al}_{2} \mathrm{O}_{3}$ 及び $\mathrm{SiO}_{2}$ の平均泳動速度である. $\mathrm{pH}=4.4$ の条件で調製したスラ リーの泳動速度分布は $\gamma-\mathrm{Al}_{2} \mathrm{O}_{3}$ と $\mathrm{SiO}_{2}$ の中間的な位置に単一 のピークが観察され，均一なべテロ凝集状態となっていると考 えられる。一方, $\mathrm{pH}=6.0$ 付近では $\gamma-\mathrm{Al}_{2} \mathrm{O}_{3}$ のピークに近い位 置に強いピークが観察され， $\gamma-\mathrm{Al}_{2} \mathrm{O}_{3}$ と $\mathrm{SiO}_{2}$ の中間の位置に 小さなピークが存在する。この条件では化学量論組成の均一な ヘテロ凝集が起きておらず， $\gamma-\mathrm{Al}_{2} \mathrm{O}_{3}$ 又は $\mathrm{SiO}_{2}$ のいずれかが 過剩の凝集体を生成していると考えられる。 $\mathrm{pH}=9.5$ 付近では $\mathrm{SiO}_{2}$ 及び $\gamma-\mathrm{Al}_{2} \mathrm{O}_{3}$ 粒子とほぼ等しい泳動速度を持つ二つの ピークが観察される。したがって，この $\mathrm{pH}$ 条件では $\gamma-\mathrm{Al}_{2} \mathrm{O}_{3}$ と $\mathrm{SiO}_{2}$ のへテロ凝集がほとんど起きておらず， $\gamma-\mathrm{Al}_{2} \mathrm{O}_{3}$ と $\mathrm{SiO}_{2}$ が分離していると考えられる。

次にヘテロ凝集過程を評価するため, $\mathrm{pH}=9.5$ の条件でボー ルミル混合後, 希硝酸を添加して $\mathrm{pH}$ を9.5から徐々に減少さ せ，所定の $\mathrm{pH}$ において $10 \mathrm{~min}$ かくはん後，電気泳動速度分 布を求めた結果を図 3 に示した。 $\mathrm{pH}$ を減少させると $\mathrm{pH}=9.5$ の上きに認められた $\mathrm{SiO}_{2}$ 及び $\gamma-\mathrm{Al}_{2} \mathrm{O}_{3}$ の位置に存在したピー クはほとんど認められなかった。このことは，原料粒子が何ら かのへテロ凝集を起こしていることを示している.しかし， ピークは単一でなく bimodal となっており，ヘテロ凝集状態

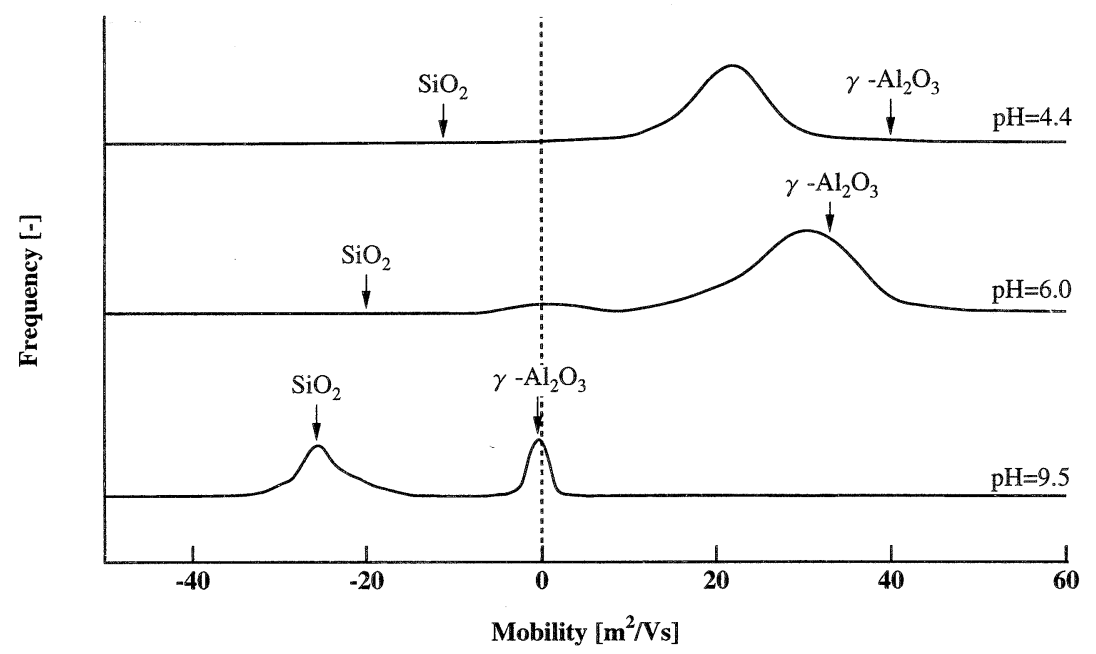

Fig. 2. Electrophoretic mobility distribution in $\gamma-\mathrm{Al}_{2} \mathrm{O}_{3}$ and $\mathrm{SiO}_{2}$ suspension with a ball-milling at $\mathrm{pH}=4.4,6.0$ or 9.5 .

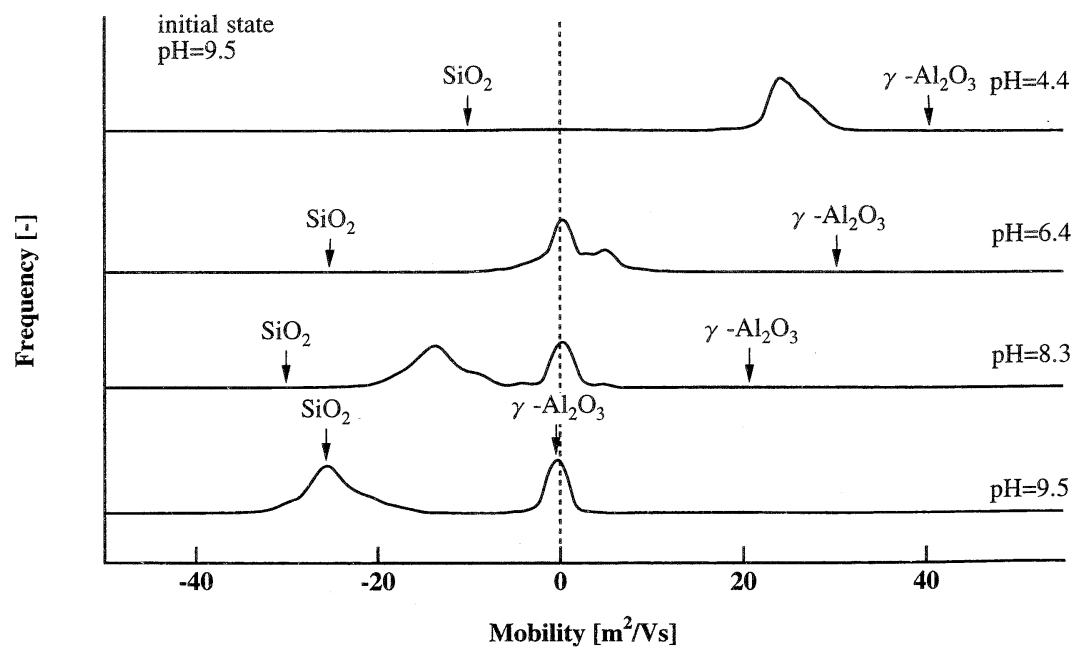

Fig. 3. Effect of $\mathrm{pH}$ on electrophoretic mobility distribution of $\gamma-\mathrm{Al}_{2} \mathrm{O}_{3}$ and $\mathrm{SiO}_{2}$ suspension ball-milled at $\mathrm{pH}=9.5$ for $24 \mathrm{~h}$. 
は均一でなく $\gamma-\mathrm{Al}_{2} \mathrm{O}_{3}, \mathrm{SiO}_{2}$ のいずれかが多くへテロ凝集して いることが予測される， $\mathrm{pH}=4.4$ まで下げると単一のピークに 近づき均質なへテロ凝集体を生成していると考えられる。

$\mathrm{pH}=9.5$ でボールミル混合した $\gamma-\mathrm{Al}_{2} \mathrm{O}_{3} / \mathrm{SiO}_{2}$ スラリーを泳 動速度分布と同様に $\mathrm{pH}$ を4.4まで下げて敌集粒度分布を遠心 沈降法で測定した結果を図 4 に示した。 $\mathrm{pH}$ を5.4まで下げて も凝集粒子径分布はほ上んど变化しない。しかし $\mathrm{pH}=4.4$ な で下げると凝集粒子径の分布が微粒子側ヘシフトしている。し たがって，ヘテロ凝集体は $\mathrm{pH}=4$ 前後の条件が最も均一で細 かい凝集体が得られることが示された。

次にこれまでの結果で最も良好なへテロ凝集状態であると予 測される $\mathrm{pH}=4.4$ 付近で $24 \mathrm{~h}$ ボールミル混合を行ったスラリー にアンモニア水を添加し, $\mathrm{pH}=9.5$ まで変化させて $10 \mathrm{~min}$ 混 合し, へテロ凝集状態の安定性を検討した結果を図 5 に示した。 $\mathrm{pH}=7.1$ なて $\mathrm{pH}$ を变化させても分布は均一であり， $\gamma-\mathrm{Al}_{2} \mathrm{O}_{3}$ と $\mathrm{SiO}_{2}$ の中間的な位置にピークがあることから均一なへテロ 凝集体であると思われる。 $\mathrm{pH}=8.2,9.5$ では bimodal な分布と なるが，図 3 に示したような $\mathrm{pH}=9.5$ でボールミル混合した 場合の $\gamma-\mathrm{Al}_{2} \mathrm{O}_{3}$ 之 $\mathrm{SiO}_{2}$ 粒子の明確な分離は認められなかった。 したがって, $\mathrm{pH}=7.1$ 以下の比較的低い $\mathrm{pH}$ で生成したへテロ 凝集は10 min 程度のかくはん混合では分離し難い, 比較的強 い凝集と考えられる。同様な方法で $\mathrm{pH}$ を調整して測定した凝 集粒度分布を図 6 に示した。 $\mathrm{pH}$ の上昇に従い凝集粒子径の増

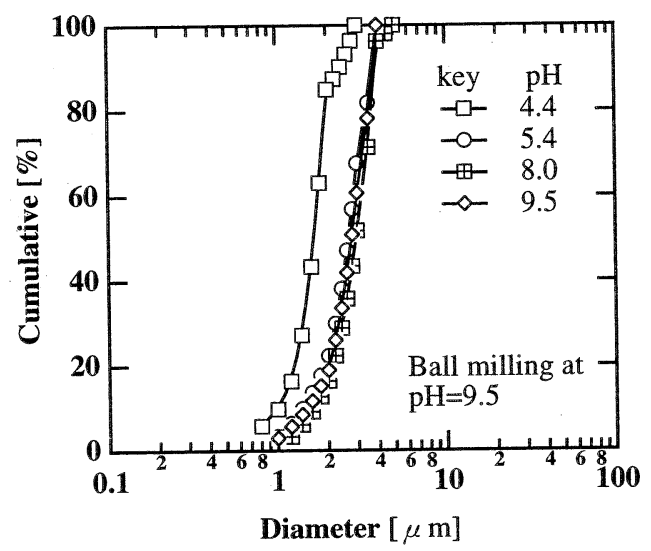

Fig. 4. Effect of $\mathrm{pH}$ on aggregates size distribution in suspension prepared by a ball-milling at $\mathrm{pH}=9.5$ for $24 \mathrm{~h}$.

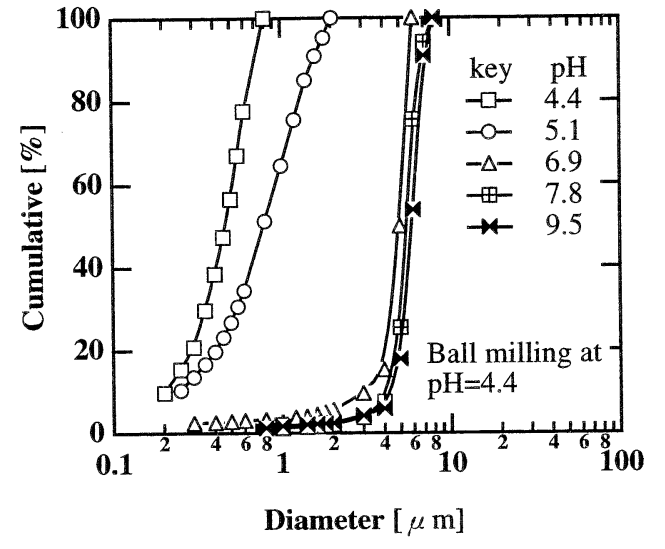

Fig. 6. Aggregates size distribution in suspension prepared by a ball-milling at $\mathrm{pH}=4.4$ for $24 \mathrm{~h}$.

加が観察され，特に $\mathrm{pH}=6.9$ 以上では $\mathrm{pH}=4.4$ に比べ 10 倍以 上の大きさをもつ凝集粒子に成長していることを示している.

この結果から，いったん生成したへテロ凝集体は比較的安定で あるが, $\mathrm{pH}$ の変化により再凝集が発生することが認められ た.

\subsection{DLVO 理論に基づいたへテロ疑集状態の解析}

以上の $\mathrm{pH}$ 変化によるへテロ凝集状態の変化を考察するた め, 異種粒子間の界面電気二重層による静電相互作用ポテン シャル $\left(V_{\mathrm{R}}\right)$ と van der Waals カによるポテンシャル $\left(V_{\mathrm{A}}\right)$ の和 $\left(V_{\mathrm{T}}\right)$ を(1)式より計算し, 結果を図 7 に示した。

$$
\begin{aligned}
V_{\mathrm{T}}= & \frac{\varepsilon d_{\mathrm{p} 1} d_{\mathrm{p} 2}\left(\Psi_{1}^{2}+\Psi_{2}^{2}\right)}{8\left(d_{\mathrm{p} 1}+d_{\mathrm{p} 2}\right)}\left[\frac{2 \Psi_{1} \Psi_{2}}{\left(\Psi_{1}^{2}+\Psi_{2}^{2}\right)}\right. \\
& \left.\times \ln \left\{\frac{1+\exp (-\kappa h)}{1-\exp (-\kappa h)}\right\}+\ln \{1-\exp (-2 \kappa h)\}\right] \\
& -\frac{A d_{\mathrm{p} 1} d_{\mathrm{p} 2}}{12\left(d_{\mathrm{p} 1}+d_{\mathrm{p} 2}\right) h}
\end{aligned}
$$

この式は粒子の表面電位 $\left(\Psi_{1}, \Psi_{2}\right)$ ，粒子径 $\left(d_{\mathrm{p} 1}, d_{\mathrm{p} 2}\right)$ が異な るへテロ系で Poisson-Boltzmann 式を解いて得られる式で表 面電位が比較的低い $\left(\Psi_{1}, \Psi_{2}<25 \mathrm{mV}\right)$, Debye-Huckel の仮定 を用い，表面電荷密度一定の条件で導いた式である20)。 なた (1) 式は Poisson-Boltzmann 式の解析解を得るため, 積分範囲 を2粒子中心間を結んた線付近の粒子表面に限定するDerjaguinの近似を用いている。

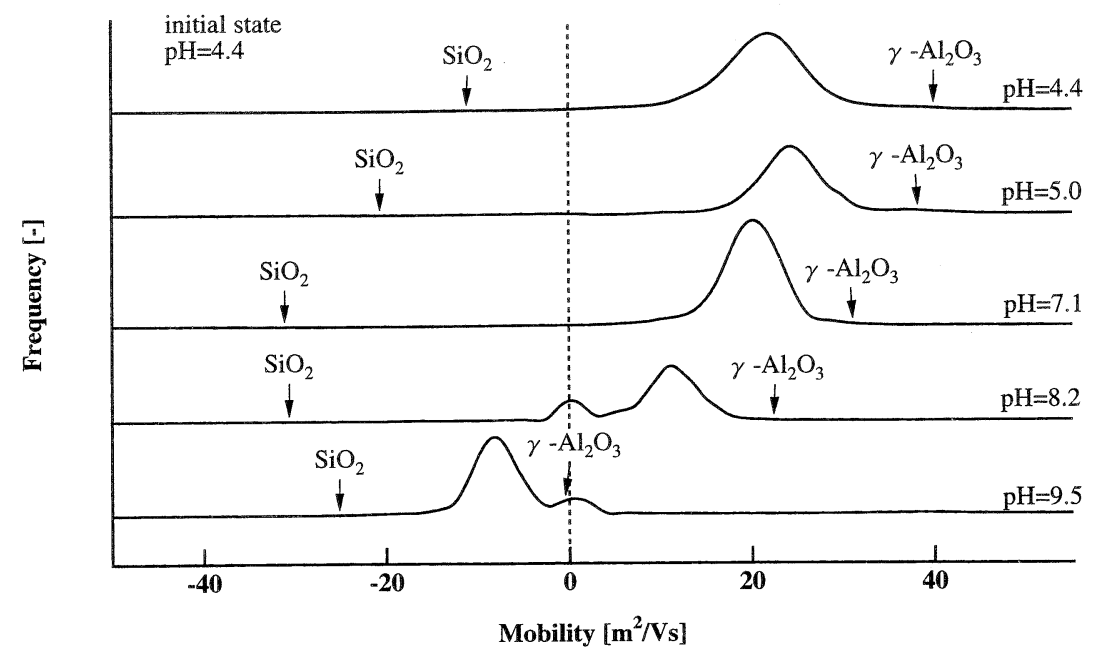

Fig. 5. Electrophoretic mobility distribution of $\gamma-\mathrm{Al}_{2} \mathrm{O}_{3}$ and $\mathrm{SiO}_{2}$ suspension ball-milled at $\mathrm{pH}=4.4$ for $24 \mathrm{~h}$. 


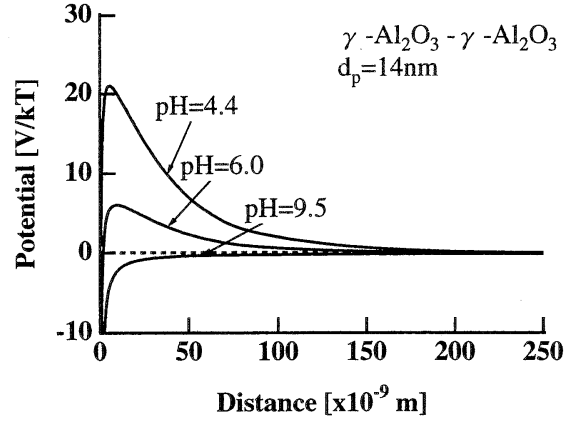

(A)

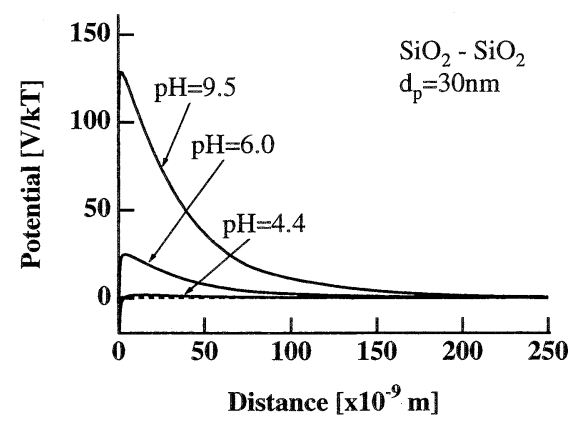

(B)

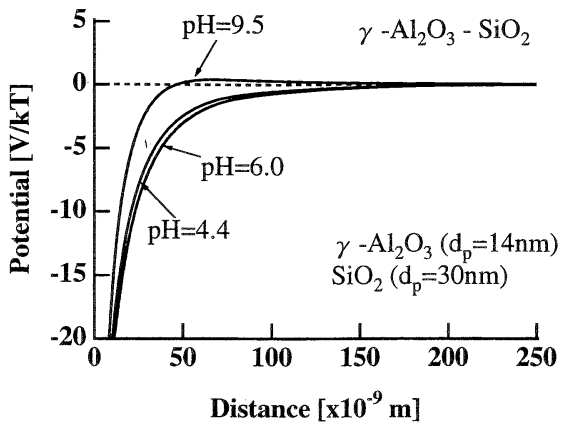

(C)

Fig. 7. Total interaction potential curves between two identical sphere particles calculated from constant surface potential type DLVO model. (A) $\gamma-\mathrm{Al}_{2} \mathrm{O}_{3}$ and $\gamma-\mathrm{Al}_{2} \mathrm{O}_{3}$, (B) $\mathrm{SiO}_{2}$ and $\mathrm{SiO}_{2}$, (C) $\gamma-\mathrm{Al}_{2} \mathrm{O}_{3}$ and $\mathrm{SiO}_{2}$.

更に $h$ は粒子表面間距離, $A$ は Hamaker 定数, $1 / \kappa$ は電気 二重層の厚さを表し, $\kappa$ は(2)式で定義される.

$$
\kappa=\sqrt{\frac{8 \pi n Z^{2} e^{2}}{\varepsilon k T}}
$$

ここで, $n$ は対イオンの個数濃度, $Z$ は対イオンの価数, $e$ は 電気素量, $\varepsilon$ は溶液の誘電率, $k$ は Boltzmann 定数, $T$ は絶対 温度である.

粒子の表面電位 $\Psi_{1}, \Psi_{2}$ は溶液中の電位決定イオンの濃度に よって決定されるが, 酸化物の場合は $\mathrm{H}^{+}$又は $\mathrm{OH}^{-}$が電位決 定イオンとなり $25^{\circ} \mathrm{C}$ 水溶液では(3) 式の Nernst の式で与えら れるとして計算した。

$$
\Psi_{i}=\frac{2.3 k T}{e}\left(\mathrm{pH}_{0 i}-\mathrm{pH}\right)
$$

ここで, $\mathrm{pH}_{0 i}$ は $i$ 粒子の等電点であり, $\gamma-\mathrm{Al}_{2} \mathrm{O}_{3}$ では9.0, $\mathrm{SiO}_{2}$ では3.0を用いた。 Nernstの式より求めた $\gamma-\mathrm{Al}_{2} \mathrm{O}_{3}$ と $\mathrm{SiO}_{2}$ 粒 子の各 $\mathrm{pH}$ での表面電位は表 1 に一括して示した。一般にポテ ンシャル障壁の大きさが $k T$ の $10 〜 20$ 倍以上あれば微粒子は分

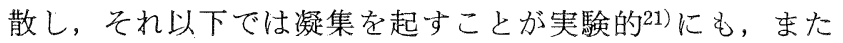
Brownian dynamic 法を用いた計算機シミュレーションによっ ても確認されている22). Hogg らによると(1)式は表面電位が 50 60 mV 以下の範囲であまり大きな䛊差を生じないとされ ている ${ }^{20)}$. 表 1 の值はこの報告より高い表面電位となる条件 もあるが, Debye-Huckel近似を用いるとポテンシャル障壁を 低く見積もる傾向があること䗷して留抢けば粒子間の相 互作用エネルギーによる、へテロ凝集の定性的予測は十分可能で 岕ると考えられる。

$\gamma-\mathrm{Al}_{2} \mathrm{O}_{3}$ 同士のポテンシャルを示した図 7 (A) では, $\mathrm{pH}=$ 4.4 付近でポテンシャル障壁は大きいものの, $\mathrm{pH} \geqq 6.0$ ではポ

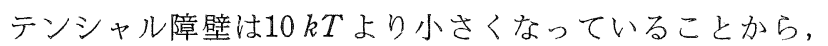
$\gamma-\mathrm{Al}_{2} \mathrm{O}_{3}$ 粒子は凝集することが予測される. $\mathrm{SiO}_{2}$ 粒子同士の結 果を示した図 7 (B) では逆に $\mathrm{pH}=4.4$ 付近で静電ポテンシャル は低く静電反発力の作用は弱いことを示している. しかし， $\mathrm{SiO}_{2}$ の場合には表面シラノール基に水素結合した水分子によ る水和斥力により等電点付近でもほとんど凝集しないことが報 告されている23). したがって, 等電点付近でも粒子はそれほ ど激しく凝集しないと考えられる. また図 7 (C) の $\gamma-\mathrm{Al}_{2} \mathrm{O}_{3}$ と $\mathrm{SiO}_{2}$ 間のポテンシャルでは $\mathrm{pH}=4.4,6.0$ の両粒子の電位が正 負反対である場合, 引力側のみが働きへテロ凝集は促進される. $\mathrm{pH}=9.5$ 付近では斥力側にポテンシャルが認められるが, その ポテンシャル障壁は10 kTよりかなり低く，ヘテロ凝集が全く 起こらないとは限らない。

この計算結果及び泳動速度分布, 凝集粒子径分布の測定結果
Table 1. Surface Potentials on $\gamma-\mathrm{Al}_{2} \mathrm{O}_{3}$ and $\mathrm{SiO}_{2}$ Particles

\begin{tabular}{|c|c|c|}
\hline $\mathrm{pH}$ & \multicolumn{2}{|c|}{ surface potential $\Psi_{0 \mathrm{i}}=0.059\left(\mathrm{pH}_{0 \mathrm{i}}-\mathrm{pH}\right)$} \\
\hline & $\begin{array}{c}\gamma-\mathrm{Al}_{2} \mathrm{O}_{3}\left(\mathrm{dd}_{\mathrm{P}}=14 \mathrm{~nm}\right) \\
{[\mathrm{mV}]}\end{array}$ & $\begin{array}{c}\mathrm{SiO}_{2}\left(\mathrm{~d}_{\mathrm{P}}=30 \mathrm{~nm}\right) \\
{[\mathrm{mV}]}\end{array}$ \\
\hline 4.4 & 271.4 & -82.6 \\
\hline 6.0 & 177 & -177 \\
\hline 9.5 & -29.5 & -383.5 \\
\hline
\end{tabular}
Calculated from Nernst Equation at $\mathrm{pH}=4.4,6.0$ or 9.5

から想定される $\mathrm{pH}$ によるへテロ凝集状態の変化を図 8 に示し た. $\mathrm{pH}=4.4$ 付近では $\mathrm{SiO}_{2}$ がわずかに凝集しているものの, $\gamma-\mathrm{Al}_{2} \mathrm{O}_{3}$ は高い表面電位を維持するため比較的分散した状態で $\mathrm{SiO}_{2}$ とヘテロ凝集している． $\gamma-\mathrm{Al}_{2} \mathrm{O}_{3}$ 同士の凝集が起きず $\mathrm{SiO}_{2}$ も水和斥力によりほとんど凝集しないため, 両粒子が比 較的均一に混合されたへテロ凝集体となる。また，へテロ凝集 体同士の凝集はほとんど起こらず，凝集粒子径は小さい，一方， $\mathrm{pH}=6.0$ 付近になるとへテロ凝集する前に $\gamma-\mathrm{Al}_{2} \mathrm{O}_{3}$ 同士が凝集 体を形成し，分散している $\mathrm{SiO}_{2}$ の間に大きな $\gamma-\mathrm{Al}_{2} \mathrm{O}_{3}$ 凝集体 が存在する。このため, $\gamma-\mathrm{Al}_{2} \mathrm{O}_{3}$ 過剰のへテロ凝集体となる。 余った $\mathrm{SiO}_{2}$ は $\mathrm{SiO}_{2}$ 過剰の凝集体を生成し, 系全体として不 均一な構造となる. $\mathrm{pH}=9.5$ 付近では, $\gamma-\mathrm{Al}_{2} \mathrm{O}_{3}$ の凝集体が生 成し $\mathrm{SiO}_{2}$ はへテロ凝集をわずかに生成する可能性があるもの の，ほとんど分離している状態と考えられる。

\section{3 ヘテロ疑集体の顆粒体構造}

$\mathrm{pH}=4.4,6.0,9.5$ の条件で調製した $\gamma-\mathrm{Al}_{2} \mathrm{O}_{3} / \mathrm{SiO}_{2}$ スラリー を噴霧乾燥して得られた顆粒体内部の細孔径分布を水銀王入法 により測定した結果を図 9 に示した。細孔径は $\mathrm{pH}=6.0,9.5$,

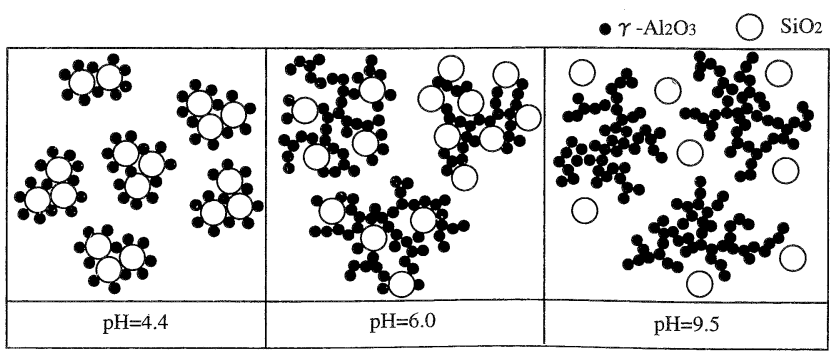

Fig. 8. Illustration of hetero-coagulation structure with different $\mathrm{pH}$ conditions. 


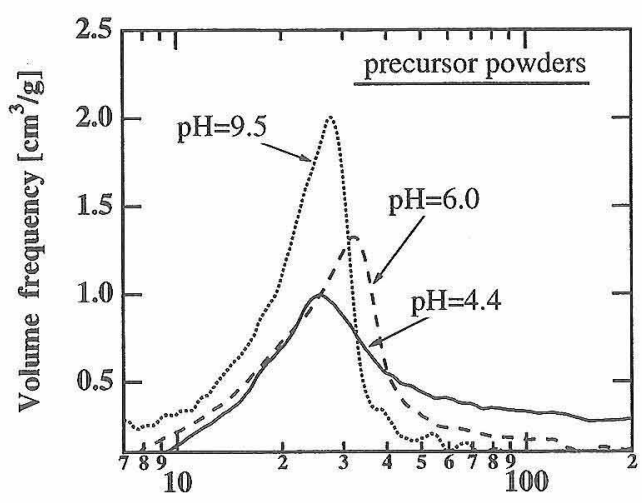

Pore diameter [nm]

Fig. 9. Effect of pH during colloidal mixing process on pore size distributions of spray-dried granules.

4.4の順で減少している. むた細孔体積も $\mathrm{pH}=4.4$ 付近の場合 が最も小さい。この結果から $\mathrm{pH}=4.4$ 付近の場合は, 均一で あるとともに緻密な顆粒体になっていると考えられる。

\section{4 焼結体微構造}

ヘテロ凝集構造の $\mathrm{pH}$ による変化が微構造に及ぼす影響を検 討するために SEM 観察を行い，その結果を図10に示した，各 焼結体之も CIP 压 $1.0 \mathrm{GPa}$ の条件で成形し， $1600^{\circ} \mathrm{C}$ で $2 \mathrm{~h}$ 保持 して倠結した。均一なへテロ凝集体が得られる $\mathrm{pH}=4.4$ 付近 （図10(A)）の場合には, 焼結体微構造も比較的均一で結晶粒 子径は $1 \mu \mathrm{m}$ 前後にほぼそるっている。しかし，均一なへテロ 凝集の生成が困難な $\mathrm{pH}=9.5$ 付近（図 $10(\mathrm{C})$ ), 及び $\mathrm{pH}=4.4$ の場合に比べ均一性が劣ると考えられる $\mathrm{pH}=6.0$ 付近（図 10(B)）の場合には不均一な異常粒成長が観察された。 以上の 結果よりヘテロ凝集状態は焼結体微構造に及ぼす影響が大き く, ヘテロ凝集の均質化之凝集体サイズの微細化が焼結体微楧 造の微細化, 均質化に有効であることが確認された。

本報の泳動速度分布よりへテロ凝集状態を推定する方法はム ライト以外の各種コロイド混合系, 楛結助剂等を添加する系な ぞ大半の異種粒子混合系で有効であると考えられる。

\section{4. 結 論}

$\gamma-\mathrm{Al}_{2} \mathrm{O}_{3}$ 及び $\mathrm{SiO}_{2}$ コロイド混合粒子の $\mathrm{pH}$ によるへテロ凝集 構造の変化が電気泳動速度分布及び遠心沈降法による凝集粒度 分布から推定できた，特に， $\mathrm{pH}=4.4$ 付近に設定し， $24 \mathrm{~h}$ ボー ルミル粉䂥したコロイド混合系で最も均質なへテロ凝集体が得
られた。このへテロ凝集体は比較的高 $\mathrm{pH}$ 側に $\mathrm{pH}$ を調整して もへテロ凝集した $\gamma-\mathrm{Al}_{2} \mathrm{O}_{3}$ と $\mathrm{SiO}_{2}$ が再分離せす，安定なへテ ロ凝集体となっていることを確認した．前駆体のへテロ凝集構 造は，焼結体微構造の微細化と均一化にも影響し，コロイド混 合の最適へテロ凝集条件は $\mathrm{pH}=4.4$ 付近で達成できることを 示した。

\section{文献}

1) I. A. Aksay, D Dabbs and M. Sarikaya, J. Am. Ceram. Soc., 74, 2343-58 (1991).

2) I. A. Aksay and J. A. Pask, J. Am. Ceram. Soc., 58, 507-12 (1975).

3) J. A. Pask, Ceram. Int., 9, 107-13 (1983).

4）鈴木久男, 友清芳二, 陶山容子, 斎藤 肇, セラミックス諭 文誌, 96, 67-73 (1988).

5) B. E. Yoldas, Am. Ceram. Soc. Bull., 59, 479-83 (1980).

6) K. Okada and N. Otsuka, J. Am. Ceram. Soc., 70, C245-47 (1987).

7) B. E. Yoldas and D. P. Partlow, J. Mater. Sci., 23, 1895-900 (1988).

8) J. C. Huling and G. L. Messing, J. Am. Ceram. Soc., 72, 1725-29 (1989)

9) H. Kamiya, H. Suzuki, T. Ichikawa, Y. I. Cho and M. Horio, J. Am. Ceram. Soc. (1998) 印刷中.

10) D. X. Li and W. J. Thomson, J. Mater. Res., 5, 1963-69 (1990).

11) S. Rajendran, H. J. Rossell and J. V. Sanders, J. Mater. Sci., 25, 4462-71 (1990).

12) G. Klaussen, G. S. Fischman and J. L. Laughner, Ceram. Eng. Sci. Proc., Vol. 11 (1990) pp. 1087-93.

13) J. C. Huling and G. L. Messing, J. Am. Ceram. Soc., 74, 2374-81 (1991).

14) H. Kamiya, H. Suzuki, T. Ichikawa and G. Jimbo, Ceram. Eng. Sci. Proc., Vol. 13 (1992) pp. 567-71.

15) Y. I. Cho, H. Kamiya, Y. Suzuki, H. Suzuki and M. Horio, J. Eur. Ceram. Soc. (1998) 印刷中.

16) K. Furusawa and C. Anzai, Colloids Surfaces, 63, 103-11 (1992).

17) W. Y. Shin, W. H. Shin and I. A. Aksay, J. Am. Ceram. Soc., 79, 2587-91 (1996).

18) H. M. Jang and J. H. Moon, J. Ceram. Soc. Japan, 102, 63341. (1994).

19) H. Kamiya, H. Suzuki, D. Kato and G. Jimbo, J. Am. Ceram. Soc., 76, 54-64 (1993).

20) R. Hogg, T. W. Healy and D. W. Fuerstenau, Trans. Faraday Soc., 62, 1638-51 (1966).

21) C. M. Bagnall, L. G. Howarth and P. F. James, J. Non-Cryst. Solids, 121, 56-60 (1990).

22) H. Takano, H. Kamiya and M. Horio, J. Am. Ceram. Soc., 投 稿中.

23) H. Kamiya, M. Mitsui, S. Miyazawa, H. Takano and M. Horio, J. Am.Ceram. Soc.，投稿中.
(A)

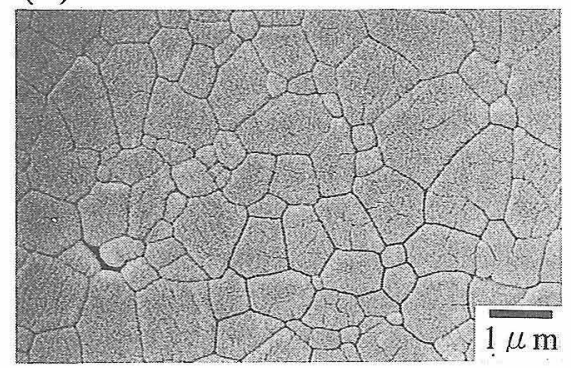

(B)

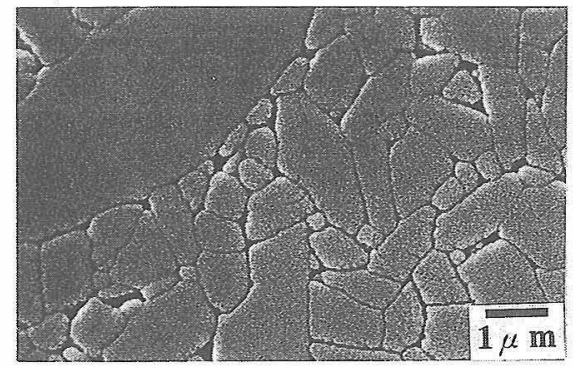

(C)

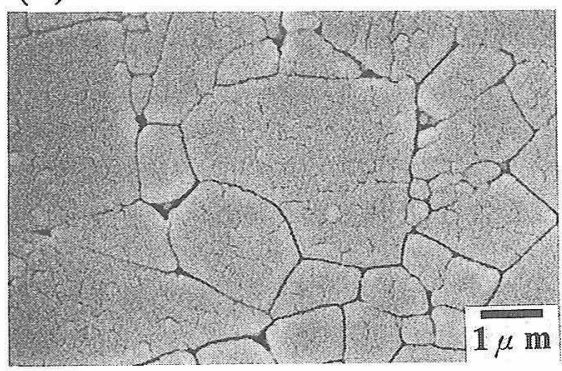

Fig. 10. SEM photographs of polished and thermally etched mullite ceramics sintered at $1600^{\circ} \mathrm{C}$ for $2 \mathrm{~h}$. (A) $\mathrm{pH}=4.4$, (B) $\mathrm{pH}=6.0$, (C) $\mathrm{pH}=9.5$. 